\title{
SOME FEATURES OF DEVELOPMENT IN THE AGRICULTURAL POLICY WESTERN BALKAN CANDIDATES FOR MARKET ACCESS IN THE EU
}

\author{
Zoran Simonović ${ }^{1}$, Slavomir Miletić2 ${ }^{2}$ Vesna Popović3 \\ *Corresponding author E-mail: zoki@medianis.net
}

A R T I C L E I N F O
Review Article
Received: 04 April 2019
Accepted: 06 May 2019
doi:10.5937/ekoPolj1902541S
UDC 338.439.01/.02(497.15:4-672EU)

Keywords:

agricultural policy, countries of the Western Balkans, CAP, EU, agriculture, market.

JEL: Q13, Q18, F15

\begin{abstract}
A B S T R A C T
The agricultural policy of Western Balkan countries in the process of accession to the European Union market is characterized by high volatility, which is expressed in terms of the applied instruments and measures as well as the product concerned. In the first phase of liberalization of prices and trade, most countries abolished or significantly reduced the customs import and export barriers to a wide range of products and also reduced or eliminated production subsidies. Only import tariffs are the only basic protection instrument for producers. Input prices have increased considerably for producers, which has led to a decrease in income in agriculture. In reality, this meant that domestic agricultural production was left to the ruthless competition of EU countries that have far better developed agricultural and food production. In the past few years, the implementation of the new agrarian policy, in countries from the first round of accession candidates, the European Union has introduced budget support measures for producers, mainly in the form of payments per hectare or throat. These budget payments were made according to the model of the EU CAP.
\end{abstract}

(C) 2019 EA. All rights reserved.

\section{Introduction}

Due to the process of globalization, the development of international cooperation between countries, as well as between international organizations, has been of

1 Zoran Simonović, $\mathrm{PhD}$, Research associate, Institute of Agricultural Economics, Belgrade, Volgina St. No.15, Phone: + 381 (0) 11697 2858, e-mail: zoki@medianis.net, ORCID ID (https://orcid.org/0000-0002-2769-6867).

2 Slavomir Miletić, PhD, University of Priština, Faculty of Economics, Kolašinska street 156, Kosovska Mitrovica, Serbia, phone: +38163424987, e-mail: mil.slavko@gmail.com, ORCID ID: https://orcid.org/0000-0003-2433-0867;

3 Vesna Popović, PhD, Principal Research Fellow, Institute of Agricultural Economics, Belgrade, Volgina St. No.15, Phone: +381 11 6972854, e-mail:vesna_p@iep.bg.ac.rs, ORCID ID (https://orcid. org/0000-0003-1018-2461). 
increasing importance (Dudić et al., 2018). The agricultural policy of the candidate countries is characterized by high volatility expressed in terms of the instruments and measures applied, as well as the product concerned, to which it applies (EC, 1998a). In the first phase of liberalization of prices and trade, most countries abolished or significantly reduced non-tariff import and export barriers for a wide range of products. Also, most countries have reduced or eliminated production subsidies and left import tariffs as the primary instrument for protecting producers. Input prices have increased considerably for producers, which has led to a decrease in income in agriculture. This trend took place in most of the candidate countries from the Western Balkans sometime between 1990 and 1992. (Volk, 2004).

Later on, due to the negative effects of the transition itself and the real decline in income, ad-hoc price and foreign trade interventions were introduced in many countries in the function of stabilizing agriculture and protecting consumers and producers. Countries from the territory of the Balkan Peninsula had a late transition caused by the political reasons caused by the breakup of the SFR Yugoslavia (Croatia, Bosnia and Herzegovina, Serbia and Montenegro). For this reason, they have led a strictly controlled agrarian policy.

In the past few years, the implementation of the new agrarian policy, in countries from the first round of accession candidates, the European Union has introduced budget support measures for producers, mainly in the form of payments per hectare or throat. First of all, we are referring to Slovenia as the only country in Southeast Europe that has met the standard for this type of support. These budget payments were made according to the model of the Common Agricultural Policy (CAP) of the EU. In the field of rural development policy, the adjustment of measures practically in all these countries was at this stage at the initial stage. (OECD, 2002).

In principle, the strategic goals of these countries are more or less aligned with EU principles and can be summarized in ensuring the stable production of quality food with reasonable prices and the safety of this food; sustainable resource management; increasing the effectiveness and ensuring an adequate standard of living (income) for agricultural producers and the rural population. However, in terms of operational programs and implementation of agrarian policy, as well as adaptation of CAP, there are great differences between countries. (Volk, et al., 2015; Gandolfi et al., 2018; Booth, 2018).

Slovenia and Croatia are already in the European Union. A sufficient element of harmonization with EU legislation and program documents, especially in the field of rural development SAPARD5 (2005-2006) and IPARD6 (2007-2013) programs can be found in Macedonia, where IPARD programs are being prepared and implemented, and in Montenegro, where at the programming level, all documents (strategies, national program, legislation) have been prepared in accordance with EU principles. Rural development program documents that were drafted on the basis of EU rural development regulations were adopted in Albania and Serbia. Bosnia and Herzegovina has a specific situation because there is no single Ministry of Agriculture at the state level. There are two separate strategies for agriculture and rural development at the entity level, 
while agricultural policy is partially applied even at lower levels (cantonal). Although program documents and planned activities in these countries are closely related to EU integration, agrarian policy is still largely implemented on the basis of annual budget allocation programs that are not stable in terms of resources, support measures and criteria. (Volk, 2010).

In most of these countries, the main strategic document is complemented by a multiyear program for its implementation. At the same time, the IPARD Instrument for Pre-Accession Assistance (IPARD) programs have also been prepared as key issues concerning pre-accession EU support in the fields of agriculture, institution building and the improvement of the agricultural sector. However, the establishment of the necessary institutions for the implementation of the IPARD program has not yet been met by any Western Balkan countries, except for Northern Macedonia, which has led to delays in the use of EU funds.

\section{Materials and methods}

In this paper, the authors used methods that best reflect the character of the analysis given in the title of the topic. In the research of the development of agrarian policy of the countries of the Western Balkans, they were dominated by quantitative methods of economic analysis. In the first place, these are various legal texts, statistical data and literary sources related to the application of agrarian policy. An analysis of the content of secondary data sources was also used during the research. Secondary data, information on the history of CAP and its reforms were taken mainly from official documents of the European Commission and relevant literature. A comparative statistical survey on the application of agrarian policy in the countries of the Western Balkans is particularly emphasized. It should be noted that Internet information was also used which are numerous and significant.

The contribution of this paper is reflected in the review and analysis related to the state of subsidies in agriculture in the countries of the Western Balkans. It is pointed out that it is necessary to align agricultural policy with the CAP, but also to preserve certain peculiarities in individual agricultural production. This can be done by more efficient implementation of measures of agrarian policy, in which the creation of the state must involve larger individual agricultural producers. What the text of this paper we believe confirms.

In this paper, the authors tried to point out that a well-organized agrarian policy can be an advantage in the organization of agricultural production. The result of this research is, as you can see from the text of the paper, an attempt to get to know the full role and full significance of a well organized system of subsidies as a potential model for faster start-up of economic activities.

A special contribution was made in the work of the research work, which was elaborated on the basis of a comparative statistical survey on the progress of agricultural policy development in the countries of the Western Balkans. 
In this paper, the authors tried to give an insight into the current situation in the application of agrarian policy in the agriculture of the Western Balkans. They believe that this is necessary today when the agrarian countries of the Western Balkans are preparing for accession to the European Union.

\section{Results and Discussions}

\section{CAP as the best model for the countries of the Western Balkans}

For this reason, we want to emphasize that negotiations with the countries of the Western Balkans represent the next significant step in the development of the CAP. The countries in this part of Europe are in principle agricultural land with low productivity and low prices of agricultural products that need to be completely restructured. These countries can be reintegrated into CAP only by respecting the rules and with the help of EU member states. In practice, this would mean that the level of productivity and prices of agricultural products will be competitive with the CAP and the EU countries. The Directorate-General for Agriculture and the Commission calculate that the transition period and the period after accession are significant for harmonization with the new CAP system. The total amount of support for these countries would be between 12 and 15 trillion Eco, including all important investments in all types of infrastructure, economy and development. Also, from the Joint Structural Fund, it is planned to allocate 15 trillion EEK per year. (European Commission, 1997). Foreign direct investment is crucial to the development of the world economy (Dudić et al., 2018) which inflow can be affected by exit from EU (ex. Brexit) (Gudgin et al., 2018; Orazulike, 2018).

After 2004, when eight countries of Eastern and Central Europe joined the European Union, increased aid to farmers. There has been an integration of the agrarian policy regimes of these eight countries with the EU Common Agricultural Policy. In this same year, assistance to the agricultural sector of Slovenia has increased. (Anderson, Swinnen, 2008).

Various adaptation strategies may be adopted in connection with the requirements for accession. In the last enlargement, the most successful countries were those that timely supported the construction of these institutions necessary for the implementation of the CAP, and at the same time they prepare manufacturers for procedures and levels of support that are applied after accession. Rational (taking into account opportunities and needs) and the gradual introduction of CAP as elements most closely fills this approach. Elements that no longer exist or are significantly different from those applied in the EU should not be adopted. This is especially important for candidate countries.

In the development of agriculture and agrarian policy, two elements prevail in general. The first is that the European model is successful in all aspects: productivity, quality and quantity of production, in the production of healthy food, in terms of sustainable development, waste utilization, etc. The second element is that this model is based on market principles as one of the best in the world and has a strong impact on agriculture and agrarian policy of countries in transition, primarily European. 
The development problems of the countries of the Western Balkans are much more pronounced than in the countries of Central and Eastern Europe that joined the EU in 2004. The development process, with limited domestic funds, with the grant of financial assistance on a bilateral and multilateral plan with per capita foreign direct investment that is significantly lower than that of the countries of eastern and central Europe, has not in most of these countries led to the overcoming of a transitional shock, closer approximation to the level of development of EU countries 15. (Simonović, 2014).

Despite these indicators, we can say that the impact of the European agricultural model on the agriculture of the countries of the Western Balkans is very strong and multiple.

1) - It is reflected primarily in ownership transitions or in the transfer from state (social) to private property on the ground. In other words, state farms become private. By changing ownership to the country, the possibility for entrepreneurship is realized, conditions for greater interest in successful production, better equipment, greater care and greater safety of the producers are created. This principle would primarily apply to Albania, where in the period of communist domination there were almost no privately-owned agricultural lands. In the countries of the former Yugoslavia agricultural land was mostly privately owned. There is another problem here, which is the fragmentation of agricultural possessions.

2) - The European model of agriculture offers better organization of agriculture and farmers because it is a complex system that is both vertically and horizontally connected. This division of labor in the agro-industrial system allows for a high degree of specialization, and therefore a superior productivity of labor. It is understood that such manufacturers are in the trend of scientific and technological solutions, because they are related to science and top practice.

3) - The European model of agriculture is striking in economic terms. It takes into account sustainable development, agrarian resources, and the production of healthy food. In these aspects, the European agricultural model is measured with a successful American model.

4) - The European model is exemplary for the countries of the Western Balkans, and it offers the entire European market. It is a huge market and great market opportunities. On this side, each member state can find its agrarian comparative advantages. This will result in a more successful foreign trade.

5) - Europe's agriculture is highly specialized, standardized, branded, protected and imported. This fact also drives the countries of the Western Balkans towards such developments. And in this case, it is the influence of a more successful model.

6) - In the European agricultural model we have an example of regulated agricultural and rural areas; built and arranged infrastructure: roads, irrigation systems, irrigation systems, landscaped urban settlements. The European model of agriculture has an urban-territorial advantage, which is also exemplary for the countries of the Western Balkans.

7) - The normative legal order of the European agrarian sector is at a high level and is a model for countries in the Western Balkans. 


\section{Measures of agrarian policy}

Interventions on the domestic and international markets are characterized by agrarian policy in almost all countries, where governments use a large number of often complex measures to support the agricultural sector. These measures include price support, quantitative restrictions on the production or use of inputs, budget payments, trade barriers, regression inputs, etc. All these measures affect the allocation of production resources to production sectors and regions, and therefore to the use of inputs, farm structure, income and rural economy. Generally speaking, agrarian policy has initiated growth in the use of inputs and the use of resources in agricultural production. Lovre, Zekić, (2008).

Looking at the level of liberalization in the agricultural markets of all these countries, it is quite different from countries to countries. Border protection is the subject of agrarian policy in all these countries. In the last few years the level of border protection has been minimized. For the purpose of conducting negotiations with WTO and quotas (except for preferential), they have been abolished (or not introduced into everything). Customs are set at a relatively low level in Albania, Bosnia and Herzegovina, and Northern Macedonia ( $0 \%$ to $15 \%$ ), while in Serbia ${ }^{4}$ and Montenegro customs duties for some products are higher (up to 50\%). All countries of this country have signed several free trade agreements (the most important of which is CEFTA7), which significantly reduce the level of effective foreign trade of protection so far. Overall, it can be said that the level of trade protection in these countries is relatively low.

Table 1. Forms and importance of support measures on the market

\begin{tabular}{|l|c|c|c|c|c|}
\hline & Albania & $\begin{array}{l}\text { Bosnia and } \\
\text { Herzegovina }\end{array}$ & $\begin{array}{l}\text { Northern } \\
\text { Macedonia }\end{array}$ & Montenegro & Serbia \\
\hline border protection & relative & relative & relative & relative & relative \\
\hline export support & not & not & not & not & not \\
\hline intervention in the market & not & not & not & not & not \\
\hline other support measures & - & yes & - & - & - \\
\hline
\end{tabular}

Source: Research by the author

Export subsidies (refunds) are just an important measure of market support in Serbia.

In other countries, this measure has not been implemented. Intervention in the market system is formally only in Serbia, but in recent years' interventional redemption is rarely implemented. That we can freely say that there is no longer. From other measures of market support, administered prices are realized in Bosnia and Herzegovina (for wheat and rye).

4 The most sensitive products for Serbian farmers will remain protected by payment of customs duties until Serbia joins the EU: this applies to all types of meat, yogurt, butter, certain types of cheese, honey, some types of vegetables and flour, and customs protection for these products varies from 20 up to $50 \%$ in relation to the MFN customs duties that Serbia applies to trade with the rest of the world. (https://europa.rs/srbija-i-evropska-unija/trgovina/). 
Measures of direct subsidies to producers are certainly the most important instrument of agrarian policy in all countries. This instrument contains all basic forms, except for separate payments. However, the support structure varies by country.

The most total amount of support funds received was paid based on outputs (prices), which is still very important in all observed countries, but especially in Bosnia and Herzegovina. Direct payments based on area and number of animals are the most widespread form of subsidies implemented in all countries. The importance of these payments is particularly significant in Northern Macedonia. In all these countries, the use of inputs (seeds, fertilizers, etc.) is also subsidized. In Serbia, input subsidies are the most important form of direct support to producers. The process of separating these payments is delayed in all of these countries, even though it was planned.

Table 2. Forms of direct subsidies to producers

\begin{tabular}{|l|c|c|c|c|c|}
\hline & Albania & $\begin{array}{l}\text { Bosnia and } \\
\text { Herzegovina }\end{array}$ & $\begin{array}{l}\text { Northern } \\
\text { Macedonia }\end{array}$ & Montenegro & Serbia \\
\hline $\begin{array}{l}\text { direct payments for } \\
\text { production }\end{array}$ & introduced & relative & relative & relative & relative \\
\hline $\begin{array}{l}\text { direct payments to the animal } \\
\text { domain }\end{array}$ & introduced & relative & relative & relative & not \\
\hline variable input subsidies & introduced & not & introduced & relative & relative \\
\hline separate payments & not & yes & not & not & not \\
\hline
\end{tabular}

Source: Research by the author

Support for public services in agriculture is present in all countries of Southeast Europe. More attention is given to veterinary and phyto sanitary services in candidate countries.

Table 3. Forms of direct subsidies to producers

\begin{tabular}{|l|c|c|c|c|c|}
\hline & Albania & $\begin{array}{l}\text { Bosnia and } \\
\text { Herzegovina }\end{array}$ & $\begin{array}{l}\text { Northern } \\
\text { Macedonia }\end{array}$ & Montenegro & Serbia \\
\hline renewed service & Yes & Yes & relative & relative & relative \\
\hline $\begin{array}{l}\text { veterinary and phytosanitary } \\
\text { protection }\end{array}$ & Yes & Yes & relative & relative & Yes \\
\hline other & Yes & Yes & Yes & Yes & Yes \\
\hline
\end{tabular}

Source: Research by the author

This part of agrarian policy is modestly commented on in the reports of all these countries. Therefore, a rather vague picture of the real state of things is obtained. If we observe programs by the volume of agricultural budget funds allocated for this purpose, then it could be said that the importance of public services is low in all these countries. Some experts believe that these services are financed from other sources (donors, other ministries), but without long-term financing, it is difficult to expect the development of public institutions needed for faster advancement of agriculture. 
In addition to showing the total amount allocated for support, the structure of this support, which is an indicator of agrarian policy, is also important. In this regard, Albania regularly applies a very limited number of direct support schemes (for cow's milk, sheep and goats, hives and olives), while several schemes have been applied sporadically (schemes applied for only one or two years). Support rates are comparable with other Western Balkan countries, but the relative levels of direct support that are actually paid to producers are still low (less than 6 EUR / ha CAP in 2015), although the total budget for direct support measures has increased significantly since 2010. years.

In 2015 , almost $80 \%$ of total direct support went to the livestock sector, mainly for sheep and goats $(64 \%$ of the total). The admissibility criterion for direct payments to the livestock sector is determined in a relatively narrow range (100 to 300 sheep and goats, 100 to 300 hives, and 1500 to 15000 liters of milk per month), and therefore, only a limited number of animals or quantities are supported through direct payments production. In Bosnia and Herzegovina, and after 2003, also in Montenegro, with the increase of total support, its composition is also changing. Indeed, the share of resources related to rural development measures is increasing at the expense of reducing the direct support of the producers. (Volk et all, 2017).

This means that Bosnia and Herzegovina is characterized by a very large number of different payment schemes that are specific to certain products, both for the flora and fauna, which have not changed to a large extent since the period 2011-2012, when the bulk of payments based on the total production replaced with surface payments. However, in all the years analyzed, the milk product sub-sector received about half of the total direct support (57\% in 2015), while the rest was divided among other products, each of which received a small share (generally less than 5\%. (Volk et all, 2017).

In Montenegro, direct support is mainly directed towards the dairy product sub-sector, which amounts to $56 \%$ of the total planned funds for these measures in 2015 . Together with support for the production of cattle and sheep and goats (12\%), direct payments for livestock production represent a large majority total direct support ( $80 \%$ in 2015). Only about $16 \%$ of the total resources are reserved for direct support for production of crops on arable land and tobacco, while the rest (4\%) is comprised of subsidies for crop production and livestock insurance (all products). (Volk et all, 2017).

This is not the case in Northern Macedonia, where the structure in recent years is quite rigid and the share of direct producer support has remained very high. Generally speaking, only funds in the field of dairy farming and production were paid in Northern Macedonia in 2015, which resulted in a sharp decrease in the level of total direct support in comparison with 2014 and previous years. In all years except 2015, the relative level of direct support actually paid to producers (EUR / ha KPZ) was the highest among the countries of the Western Balkans. (Volk et all, 2017).

Serbia is a special case. In addition to the significant decline in total support since 2005, a dramatic change in the direct support structure of the manufacturer can be seen over the past few years - switching from direct payments to input subsidies. The case of Serbia (and Northern Macedonia until 2004) clearly indicates the problem of the stability of agrarian policy. 
Significant changes in direct support were recorded in Serbia, where the number of payment schemes, the amount of support and the specific admissibility criteria have frequently changed since 2010. In 2010 and 2011, the highest amount of direct support was paid in the form of subsidies for inputs for crop production (seed, fuel and fertilizer). The livestock sector had support only through dairy premiums and some payment for throats for high quality breeding animals.

In 2012, individual payments per surface were introduced, and the number of subsidies for inputs and their amount declined in the coming years (for fuel about $40 \%$ and for fertilizer about $60 \%$ from 2010 to 2015). In 2012 and 2013, new payment schemes for the livestock sector (payment for slaughterhouses, livestock and hives) were introduced, which resulted in a significant increase in total direct support to cattle breeding in the years that followed. (Volk et all, 2017).

In 2015 , the criteria for direct payments for crop crops have been changed, so the maximum eligible area per user is set at 20ha (from 100ha in 2013-2014). As a consequence, total support for plant production is more than halved compared to the average for the period 2010-2014. In 2015, direct support to plant production accounted for $41 \%$ of total direct support, down from $64 \%$ in 2014 and $92 \%$ in 2010 . In livestock production, cattle breeding and milk production received most of the direct support (each $22 \%$ ), followed by the pig production subsector $(8 \%)$.

Table 4. Share of subsidies in agriculture in millions of euros in total budget expenditures of the countries of the Western Balkans

\begin{tabular}{|c|c|c|c|}
\hline Country & 2013. & 2015. & 2017. \\
\hline Albania & 20,1 & 32,4 & 30,6 \\
\hline Montenegro & 17,6 & 20,0 & 24,0 \\
\hline Bosnia and Herzegovina & 71,0 & 68,0 & 80,9 \\
\hline North Macedonia & 109,3 & 132,9 & 136,3 \\
\hline Serbia & 268,3 & 212,0 & 229,1 \\
\hline
\end{tabular}

Source: Statistical Yearbook for each of the countries in the table, sites of the Ministries of Agriculture for each of the given countries, publications of the World Bank, national agricultural development strategy.

Planned budget support to agriculture in the period 2005-2017. was the highest in 2014 and amounted to about 45.4 billion dinars, which accounted for $4.9 \%$ of the planned budget of the total budget. In the next two years, planned budget funds for agriculture have been reduced, while such a trend has been discontinued in 2017, when it increased by about 3.3 billion, or $8.2 \%$ compared to 2016, amounting to around 43.8 billions of dinars, or 354 million euros (Law on Budget of the Republic of Serbia, 2017). (Božić, Papić, 2017).

Concerning budget support, in Table 4, we presented a million euro's view of how each state allocates from its budget for agriculture. 


\section{Market-price policy}

The agrarian market in the countries of the Western Balkans is still under construction, i.e. it was not built to a sufficient degree. Only the regulation of the agrarian market involves more complex actions. Some of these actions are: selection of production, technical-technological equipment, financial loan support. Each of these questions is, we have to admit, complex. Thus, the choice of production means finding comparative agricultural products with which they would be competitive. For example, the quality of Serbian raspberry is a true brand although it is not formally branded. Therefore, the regulated agrarian market also means branding or standardization of quality. All this represents a complex job for the countries of the Western Balkans that are trying to place their agrarian products on the EU market.

Market pricing policy does not only mean financial support and support for production and price support in order to achieve competitiveness. It is precisely the market-price policy that consists of the following measures:

- Measures of market support,

- Measures of direct budget support for products and

- Other direct payments.

In the European area, different problems related to the regulation of the market are encountered in different countries. A well-regulated market for agricultural products would mean differentiated and specialized agrarian production across Europe. The process of price liberalization had different effects in the countries of the Western Balkans in relation to the countries of Central and Eastern Europe where it was more intense.

Some of the CEE countries, such as Hungary and the Czech Republic, supported the export of agricultural products by granting export credits. At the beginning of the nineties, Croatia and Albania had liberalized the prices of their agricultural products.

With the abolition of the market price control in transition countries, domestic product prices began to jump and approach the world market prices.

Price liberalization in the countries of the Western Balkans has led to a rise in the price level and a fall in domestic aggregate demand with not so easy access to foreign markets. Due to the constant presence of economic sanctions directed towards the Russian Federation, they have led to difficult opportunities for placement of agricultural products, and on the other hand, the European Union market has been largely closed for most agricultural products of countries in transition. The measures taken by the states in the first half of the nineties were ad hoc and related to import tariffs, export subsidies, minimum guaranteed prices, the determination of maximum measures and restrictions on imports. In the period that follows in the second half of the nineties and later, there is more complete liberalization of prices and trade flows of agricultural products, as well as the formulation of a more comprehensive agricultural policy. 
In that sense, if the first pillar of agrarian policy is observed, most of the funds that the countries of the Western Balkans allocate for agriculture are directed towards measures of direct support to producers. In the period during which the analysis was conducted, some market support measures (market interventions) existed only in Bosnia and Herzegovina and Montenegro (listed in the program documents). A detailed analysis is, therefore, focused only on the part of the first pillar in terms of direct support measures for producers.

Most countries in the region show a trend of increase in funds intended for direct support to producers. After 2010, the largest and most consistent increase in funding for direct support to producers was recorded in Serbia by 2013. In 2015, direct support to producers in Serbia has dropped significantly, mainly as a result of altered eligibility criteria for some measures of direct support to producers. In Bosnia and Herzegovina and Montenegro, the direct support budget for producers is stable, while significantly varies in Northern Macedonia from year to year (Table 5). Annual deviations in direct support to producers in Northern Macedonia were mainly due to delays in payment of measures implemented in previous years. In 2015, only a small amount of direct payments for this year is paid to users.

Table 5. Direct support to agricultural producers in the Western Balkans countries in millions of euros

\begin{tabular}{|l|r|r|r|}
\hline Country & 2013. & 2015. & 2017. \\
\hline Albania & 6,3 & 11,6 & 6,4 \\
\hline Montenegro & 10,1 & 12,4 & 18,7 \\
\hline Bosnia and Herzegovina & 61,3 & 62,2 & 75,8 \\
\hline North Macedonia & 90,4 & 110,0 & 106,4 \\
\hline Serbia & 239,1 & 287,0 & 207,3 \\
\hline
\end{tabular}

Source: Statistical Yearbook for each of the countries in the table, sites of the Ministries of Agriculture for each of the given countries, publications of the World Bank, national agricultural development strategy.

Relatively speaking, direct support per hectare of the CAP in 2015 totaled more than 11 million euros in Albania, 12 million euros in Montenegro, about 50 million euros in Bosnia and Herzegovina and Serbia (reduction of 81 million euros in Serbia), 60 million in Northern Macedonia (EUR 18 near 2015) The level of direct support to producers is still significantly lower than in the EU, where the average value of direct support to producers in 2015 was EUR 236 million per hectare. (Volk, et all, 2017).

\section{Problems of integral agrarian development}

The problems of the integral agrarian development of the European Union as well as its consequences on the agricultural policy of the countries in transition must be seen through the segment of the development of the CAP. The common agrarian policy, as we have already pointed out, is based on three basic principles. These are the common market, financial solidarity and orientation towards the formation of a community. 
The period of the last few decades of the last century marked the search for alternative solutions to economic development, as an antipode to the classic model of industrialization and urbanization. These search attempts for new solutions led to the theoretical and practical evaluation of ecology, natural resources and sustainable development. This has resulted in the policy of integral agrarian development, which studies specific concepts, measures and procedures for solving the problems of development, both developed countries of the European Union, as well as countries in transition, i.e. countries of new member states of the European Union and candidate countries.

Integrated agrarian development is comprehensive and comprehensive. It includes:

- Development of private property,

- Development of agriculture in accordance with natural conditions

- Development of irrigation and irrigation systems

- Development of agrarian organizations (individual agricultural holdings, cooperatives, agricultural enterprises, etc.)

- Development of vertical and horizontal connection and development of agro system

- Development of multifunctional agriculture

- Development of rural systems in the agrarian environment

- Development of sustainable development

- Development and conservation of natural resources

- Land legal regulation

- Construction of market institutions

1. agrarian brand

2. agrarian standards

3. Agricultural stock exchanges and fairs

4. various agrarian services

- System of branding, development and construction, arrangement of export study for ISO, etc.

All these points are present in the initial form. They need to further develop them and raise their level. This process requires a comprehensive work and comprehensive preparation if some results were to be achieved.

Although at various stages of development, the countries of the Western Balkans are facing similar challenges in terms of diversifying and modernizing their rural economies. the ultimate purpose of these changes relates to the strengthening of the 
competitiveness of the rural economy. natural and working resources, favorable climate and proximity to the EU market give every reason to suggest that the countries of the Western Balkans have adequate preconditions for the successful implementation of the concept of integrated rural development. However, there are numerous limitations for the development of these areas in the process of EU integration. (Vujicic, at all, 2012).

When adjusting the agrarian policy of the Western Balkan countries to integral agrarian development, attention of national governments should be directed, along with the primary orientation towards the ending of price and market liberalization, land reform, privatization, institutional reform, and above all the part of the agricultural infrastructure that is related to public goods, public services. Also, regulations related to land issues, anti-monopoly regulations, insurance regulations should be established. The customization program itself should include:

- Balance of macroeconomic and sectorial measures, i.e. compliance of the exchange rate and trade policy.

- Completion of the process of market liberalization and prices, land reform, privatization and institutional reforms.

- Public investment policy in social and economic infrastructure.

- Prevention of large agricultural holdings and the agro-industrial sector in gaining a privileged position

- The introduction of measures aimed at the development of the agrarian sector, which should be dominated by technologically developed farms that rely on their workforce. (Lovre, Trkulja, 2003).

We want to emphasize that in line with the goals of the Europe 2020 strategy, the EU has set three main goals of the new, reformed CAP - sustainable food production, sustainable management of natural resources and mitigation of climate change and balanced territorial development. Newspapers will be reflected in the 4 new umbrella regulations - the Direct Payments Regulations, the Regulation on the Common Organization of the Market in Agro-Food Products, the Rural Development Regulation and the Horizontal Regulation governing the financing, management and monitoring of the implementation of the CAP and the financing of measures in the new program for the period 2014-2020, will continue to be based on the use of funds from two EU agricultural funds - EAGF and EAFRD. (Jurišić, 2014).

\section{Conclusions}

We assume that the aim of adjusting the agrarian policies of the countries of the Western Balkans is in line with the interests of the EU, which is an increase in the welfare of the population of all its members. In order for a country to become a full member of the EU, it must make a number of changes that primarily relate to the creation of a stable legal, economic and social system, as well as a radical change in the role of the state in these 
countries. Creating conditions for developing an effective ownership and economic structure, as well as an institutional framework, are prerequisites for creating a solid market economy. Exactly stable institutions create a basis for removing deformations, crime and corruption that are burdened by the countries of the Western Balkans.

We consider that more developed countries should give the underdeveloped countries a picture of a better future. It is natural to learn from the better, to endure the impact of a more successful one. But, in the case of the European agrarian model, it is not a thoughtful model like the Colossian model, for example, but it is a real model, about the experience of more developed countries that the countries of the Western Balkans want to become.

On the other hand, countries of the European Union themselves wanted to facilitate access to new countries. In this sense, the CAP changes that were adopted before the accession of the countries of Eastern Europe to the Union indicate that the central policy is weakening towards agriculture and a kind of rationalization of agricultural policies. The best example for this claim is foreign exchange differences. These premiums were paid by the national states, and since the introduction of the euro, the exchange rate differences disappeared, the 2000 premiums were redefined in the form of national envelopes. They should serve to determine the special premiums for beef and milk.

At the end, we want to point out that the reform of legal, strategic and program documents for which the agrarian policy of the countries of the Western Balkans and the institutional structure for EU accession has been in charge for several years is the main goal of their state organs. However, the progress towards adoption and implementation of the necessary changes in the agricultural policy, especially regarding the harmonization with the CAP, must be more visible in practice. The uncertainty about the dynamics of EU accession and the latest development trends in the global and regional markets require greater concentration on the real situation and problems in the agricultural sector. Therefore, a clear political decision on the priority policy objectives (selection between competitiveness, equity and public goods) as well as the establishment of explicit targets is essential for the effective distribution of support to agriculture.

\section{Acknowledgements}

The paper is prepared within the project III 46006 Sustainable agriculture and rural development in the function of accomplishing strategic objectives of the Republic of Serbia in the Danube region, financed by the Ministry of Education, Science and Technological Development of the Republic of Serbia in the period 2011-2018.

\section{Conflict of interests}

The authors declare no conflict of interest. 


\section{References}

1. Anderson K., Swinnen J.F.M., (2008): Distortions to Agricultural Incentives in Europe's Transition Economies, The World Bank, Washington, D.C., 54.

2. Božić, D., \& Papić, R. (2017). Reform of the CAP 2014-2020 and comparison with instruments of agricultural policy in Serbia. Anali Ekonomskog fakulteta u Subotici, (38), 37-49. https://doi:10.5937/etp1604055B

3. Booth, A. (2018). ASEAN and its changing economic relations with Asia and the World. Journal of Self-Governance and Management Economics, 6(1), 33-63.

4. Branović, M. (2016). Agriculture of the Western Balkan countries within the context of EU integrations. Ekonomija: teorija i praksa, 9(4), 35-51.

5. Dower, M. (2014). Empowering rural stakeholders in the Western Balkans. European Commission, Brussels.

6. Dudić, B., Dudić, Z., Smoleň, J., \& Mirković, V. (2018), Support for foreign direct investment inflows in Serbia, Economic Annals-XXI 169(1-2), 4-11, DOI: https:// doi.org/10.21003/ea.V169-01

7. Dudić., B., Drahošová., M., Dudić., Z., Smoleň., J. (2018), The Economic and Trade Relations of Serbia with the European Union, Proceedings of the 31st International Business Information Management Association Conference, IBIMA 2018: Innovation Management and Education Excellence through Vision 2020.

8. Gandolfi, G., Regalli, M., Soana, M. G., \& Arcuri, M. C. (2018). Underpricing and long-term performance of IPOS: evidence from European intermediary-oriented markets. Economics, Management \& Financial Markets, 13(3), 11-36.

9. Gudgin, G., Coutts, K., Gibson, N., \& Buchanan, J. (2018). The macro-economic impact of Brexit: using the CBR macro-economic model of the UK economy (UKMOD). Journal of Self-Governance and Management Economics, 6(2), 7-49.

10. Jurišić, Ž. (2014). Croatian agriculture in the Common Agricultural Policy of the EU - today and tomorrow [In Croatian: Jurišić, Ž. (2014). Hrvatska poljoprivreda u zajedničkoj poljoprivrednoj politici Europske unije: sadašnjost i sutrašnjica. Civitas Crisiensis] Zavod za znanstvenoistraživački $i$ umjetnički rad Koprivničkokriževačke županije u Križevcima, 1(1), 207-221.

11. Lovre, K. M., \& Trkulja, Đ. (2003). Integrated agricultural and rural development policy of the European Union and implications for the agricultural policy of the countries in transition [In Serbian: Lovre, K. M., \& Trkulja, Đ. (2003) Integralna politika agrarnog i ruralnog razvoja Evropske unije i implikacije na agrarnu politiku zemalja u tranziciji.] Anali Ekonomskog fakulteta u Subotici, (9), 12-14.

12. Lovre, K., \& Zekić, S. (2008). The contradictions and complementarity of agrarian and rural development policies. [In Serbian: Lovre, K., \& Zekić, S. (2008). Protivrečnosti i komplementarnost agrarne i politike ruralnog razvoja.] Anali Ekonomskog fakulteta u Subotici, (20), 93. 
13. Mikuš, O., Ramani, D., \& Franić, R. (2011). Directions of the European Union Common Agrivultural Policy After 2013 [In Croatian: Mikuš, O., Ramani, D., \& Franić, R. (2011). Smjernice Zajedničke poljoprivredne politike Europske unije nakon 2013. godine.] Agronomski glasnik: Glasilo Hrvatskog agronomskog društva, 72(6), 345-358.

14. OECD. (2002): Agricultural policies in transition Economies, trends in policies and support, OECD, Paris, 27.

15. Orazulike, U. (2018). Post-Brexit Threats to Work Safety and Health Standards and Good Working Conditions in the UK. Psychosociological Issues in Human Resource Management, 6(1), 63-95.

16. Prokopijević M. (2009): European Union. [In Serbian: Prokopijević M. (2009) Evropska Unija, Službeni glasnik, Beograd.] 223.

17. Simonović, Z. (2014). Management of agriculture in Serbia in transition. [In Serbian: Upravljanje agrarom Srbije u tranziciji.] Institut za ekonomiku poljoprivrede, Beograd, 177.

18. Simonovic, Z. (2016). Development policy advisory public service in agriculture in the Republic of Serbia. Ekonomika, 62(1), 59-68. https://doi:10.5937/ ekonomika1601059S

19. Stevanović, S., \& Đorović, M. (2007). Countries in transition on the path to EU integration in the monograph "International experiences in the transition of the agrarian sector and rural areas". [In Serbian: Stevanović, S., \& Đorović, M. (2007). Zemlje u tranziciji na putu integracije u EU-poglavlje u monografiji „,Međunarodna iskustva u tranziciji agrarnog sektora i ruralnih područja“.] Društvo agrarnih ekonomista Srbije, Poljoprivredni fakultet-Institut za agroekonomiju, Beograd, 9-16.

20. Statistical Yearbook of the Republic of Serbia for 2018.

21. Statistical Yearbook of the Republic of Albania for 2017.

22. Statistical Yearbook of the Republic of Macedonia for 2017.

23. Statistical Yearbook of the Republic of Montenegro for 2016.

24. Statistical Yearbook of the Republic of Bosnia and Herzegovina for 2017.

25. Volk T. (2004): The impact of agrarian policy on the development of agriculture in Slovenia in the period of transition and accession to the European Union. [In Serbian: Volk T. (2004): Uticaj agrarne politike na razvoj poljoprivrede Slovenije u periodu tranzicije i priključenja Evropsku uniju, DAES, Beograd, 2004, 20-21.

26. Volk T. (2010): Agriculture in the Western Balkan Countries, IAMO, Leibniz, $25-$ 26.

27. Volk, T., Rednak, M., \& Erjavec, E. (2012). Western Balkans agriculture and European integration: unused potential and policy failures? Post-Communist Economies, 24(1), 111-123. https://doi.org/10.1080/14631377.2012.647631 
28. Volk T. At all, (2017). Monitoring the development trends of agricultural policies in the countries of the Western Balkans, the European Union. [In Serbian: Volk T. At all, (2017). Praćenje razvojnih trendova poljoprivrednih politika u zemljama zapadnog Balkana, Kancelarija za publikacije Evropske unije Evropska Unija, Luksemburg.

29. Vujicic, M., Ristic, L., \& Vujicic, M. (2012). European integration and rural development policy of the Republic of Serbia and West Balkan countries. Bulgarian journal of agricultural science, 4, 519-530.

30. Union européenne. Commission européenne, \& EUROSTAT. (2018). Agriculture, forestry and fishery statistics. Publications office of the European Union.

31. APP-Agricultural Policy, Plus South Eastern Europe, Retrieved from https:// publications.europa.eu/en/publication-detail/-/publication/d6429250-c06f-11e89893-01aa75ed71a1 (March 26, 2019).

32. 2018 economic reform programs of Albania, the former Yugoslav Republic of Macedonia, Montenegro, Serbia, Turkey, Bosnia and Herzegovina and Kosovo, The Commission's overview and country assessments. ISSN 2443-8014, Retrieved from https://publications.europa.eu/en/publication-detail/-/publication/d6429250c06f-11e8-9893-01aa75ed71a1 (March 25,2019). 